\title{
TINJAUAN ANTROPOLOGI HUKUM ISLAM TERHADAP PRAKTIK IJAB-KABUL DALAM TRANSAKSI JUAL BELI DI PASAR TERAPUNG BANJARMASIN
}

\author{
Muhammad Arsyadi \\ Fakultas Syari'ah dan Hukum Universitas Islam Negeri Sunan Kalijaga \\ Email : mahfud.fahrazi@yahoo.com
}

\begin{abstract}
Banjarmasin Floating Market has a different culture compared to other areas in general in the implementation of of ijab-qabul in trading contracts. In Floating Market the parties who do the practice of buying and selling, both "mandatory" to say shigat in accordance with the culture of buying and selling contracts in Banjarmasin and if not pronounce shigat, then according to the base trading in Islam and Banjarmasin society culture, then the sale is considered invalid. The principal problem of this thesis is why people in Banjarmasin floating market in transactions are still using the repetition of words on shigat ijab-qabul. This type of research uses empirical legal research with descriptiveanalytical research, which describes and explains the data, conceptions and opinions that are then analyzed in depth. This research makes the focus of study on the analysis of the practice of repetition of shigat contracts in buying and selling transactions in Banjarasin floating market, in addition to taking legal materials from the field, this research is also supported by some literature either taken from books, journals, internet and thesis which then processed deductively. Based on the results of research that has been done, it is known there are several factors that become the foundation of Banjarmasin people still use the repetition of words on shadat akadnya, as it is based on the good faith of Banjarmasin community for honesty, openness and respect for other people. This goodwill into a unique and cultural fruit of local communities that uphold the principle of openness and the principle of justice, all of this aims for the sale and purchase transactions are equally provide benefits for parties and habits are also supported by community leaders to make people believe in the culture trading contracts buy it a necessity that deserves to be continued and preserved. Moreover, the culture has noble fundamental values, specially for the sake of sincerity the parties and to achieve the benefit.
\end{abstract}

Keywords: Buy and Sell, Shigat, Floating Market 


\begin{abstract}
ABSTRAK
Pasar Terapung Banjarmasin memiliki sebuah budaya yang berbeda dibandingkan dengan daerah lain pada umumnya dalam pelaksanaan ijab-qabul akad jual beli. Di Pasar Terapung para pihak yang melakukan praktik jual beli, keduanya "wajib" mengucapkan shigat yang sesuai dengan budaya akad jual beli di Banjarmasin dan apabila tidak mengucapkan shigat tersebut, maka sesuai rukun jual beli dalam Islam dan budaya masyarakat Banjarmasin, maka jual beli tersebut dianggap tidak sah. Adapun pokok masalah skripsi ini yaitu mengapa masyarakat di pasar terapung Banjarmasin dalam bertransaksi jual-beli masih menggunakan pengulangan kata pada shigat ijab-qabul. Jenis penelitian ini menggunakan penelitian hukum empiris dengan sifat penelitian deskriptifanalitis, yaitu menjabarkan dan menjelaskan data-data, konsepsi serta pendapat-pendapat yang kemudian dianalisis secara mendalam. Penelitian ini menjadikan fokus kajian pada analisis praktik pengulangan shigat akad dalam transaksi jual beli di pasar terapung Banjarasin, selain mengambil bahan hukum dari lapangan, penelitian ini juga didukung oleh beberapa literatur baik yang diambil dari buku, jurnal, internet maupun skripsi yang kemudian diolah secara deduktif.. Berdasarkan hasil penelitian yang telah dilakukan, maka diketahui terdapat beberapa faktor yang menjadi landasan masayarakat Banjarmasin masih menggunakan pengulangan kata pada shigat akadnya, seperti karena didasari oleh ittikad baik masyarakat Banjarmasin guna kejujuran, keterus terangan dan bentuk penghormatan terhadap orang lain. Itikad baik ini menjadi sebuah keunikan dan buah budaya masyarakat lokal yang menjunjung tinggi asas keterbukaan dan asas keadilan, semua ini bertujuan agar transaksi jual beli tersebut sama-sama memberikan manfaat bagi para pihak dan kebiasaan yang turut didukung oleh tokoh masyarakat menjadikan masyarakat meyakini budaya akad jual beli tersebut suatu keniscayaan yang pantas untuk diteruskan dan dilestarikan. Terlebih budaya tersebut mempunyai nilai-nilai fundamental yang mulia, terutama demi keridhoan para pihak serta untuk mencapai kemaslahatan.
\end{abstract}

Kata Kunci : Jual Beli, Shigat, Pasar Terapung 


\section{Pendahuluan}

Jual beli adalah tukar-menukar barang dengan barang atau barang dengan uang dengan jalan melepaskan hak milik dari yang satu kepada yang lain atas dasar saling merelakan. Menurut ulama syafi'iyah jual beli adalah akad saling tukar-menukar yang bertujuan memidahkan kepemilikan barang atau manfaatnya yang bersifat abadi. ${ }^{1}$

Pada dasarnya hukum jual beli adalah halal dan riba adalah haram, namun hukum jual beli sendiri adalah sesuai dengan kondisi, bisa haram, halal, mubah atau makruh tergantung pada pemenuhan rukun, syarat maupun hal-hal lainnya. Mengenai jual beli sendiri disebutkan dalam Al-Qur'an ayat berikut :

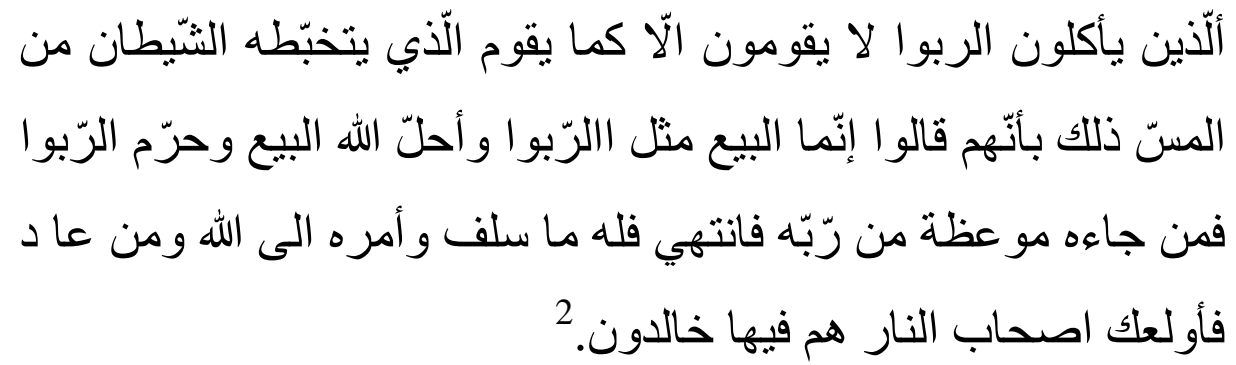

Akad jual beli dalam Islam sendiri diartikan sebagai kemauan seorang untuk melakukan jual beli yang dari dalam hatinya sendiri dan juga diartikan sebagai ikatan ijab kabul antara penjual dan pembeli untuk melakukan transaksi jual beli yang sesuai dengan syariat dalam agama Islam.

Menurut Pasal 262 Mursyid al-hairan, akad merupakan pertemuan ijab yang diajukan oleh salah satu pihak dengan kabul dari pihak lain yang menimbulkan akibat hukum pada objek akad. Menurut Syamsul Anwar akad adalah pertemuan ijab dan kabul sebagai pernyataan kehendak dua pihak atau lebih untuk melahirkan suatu akibat hukum pada objeknya.

\footnotetext{
${ }^{1}$ Hendi Suhendi, Fiqh Muamalah, cetakan ke-8, Jakarta: Rajawali, 2013, hlm. 17

${ }^{2}$ Al-Baqarah (2): 275
} 
Kedua definisi di atas memperlihatkan bahwa, pertama, akad merupakan keterkaitan atau pertemuan ijab dan kabul yang berakibat timbulnya akibat hukum. Ijab adalah penawaran yang diajukan oleh salah satu pihak, dan kabul adalah jawaban persetujuan yang diberikan mitra akad sebagai tanggapan terhadap penawaran pihak yang pertama. Akad tidak terjadi apabila pernyataan kehendak masing-masing pihak tidak terkait satu sama lain karena akad adalah keterkaitan kehendak kedua pihak yang tercermin dalam ijab dan kabul. Kedua, akad merupakan tindakan hukum dua pihak karena akad adalah pertemuan ijab yang merepresentasikan kehendak dari satu pihak dan kabul yang menyatakan kehendak pihak lain. Ketiga, tujuan akad adalah untuk melahirkan suatu akibat hukum. Lebih tegas lagi tujuan akad adalah maksud bersama yang dituju dan yang hendak diwujudkan oleh para pihak melalui pembuatan akad. ${ }^{3}$

Sebagaimana perkara muamalah lainya, dalam akad jual beli ada rukun yang harus dipenuhi. Rukun tersebut diantaranya adalah :

1.1. Dua pihak yang melakukan akad.

Dalam hal ini ada dua pihak tersebut adalah pihak penjual dan pembeli yang memenuhi syarat akad jual beli yang telah disebutkan sebelumnya. Tanpa adanya kedua belah pihak maka transaksi tidak bisa dianggap sah.

1.2. Objek dalam akad jual beli.

Dalam akad jual beli harus ada objek yang diperjual belikan. Objek tersebut bisa berupa harta benda maupun manfaat atau jasa yang dapat diambil dan diberikan nilainya. Objek dalam akad jual beli juga harus memenuhi syarat, diantaranya objek tidak merupakan barang atau harta yang haram untuk diperjualbelikan, misalnya manusia atau barang najis seperti khamar, bangkai, daging babi, anjing, narkoba dan sebagainya.

\footnotetext{
${ }^{3}$ Syamsul Anwar, Hukum Perjanjian Syariah, cetakan ke-2, Jakarta: Rajawali Pers, 2010, hlm .68-69.
} 
Objek dalam akad jual beli haruslah halal dan tidak memberikan mudharat bagi pembelinya.

\subsection{Kalimat ijab kabul (sighat al-'aqd).}

Kalimat ijab kabul atau sighat al-'aqd adalah kalimat dimana pembeli menyatakan membeli barang dari penjual tersebut mengucapkan bahwa ia menyerahkan barang atau objek jual beli tersebut kepada pembeli.

Dengan demikian setiap rukun akad jual beli dalam Islam haruslah dilaksanakan agar jual beli sah secara Islam dan tidak mendapatkan mudharat atau masalah dikemudian harinya.

Pasar Terapung Muara (Sungai) Kuin atau Pasar Terapung Sungai Barito adalah pasar terapung tradisional yang berada di atas sungai Barito di muara sungai Kuin, Banjarmasin, Kalimantan Selatan Pasar Terapung Muara Kuin merupakan pusaka sejarah Kota Banjarmasin. Para pedagang dan pembeli menggunakan jukung. ${ }^{4}$ Pasar ini memulai kegiatannya setelah sholat Subuh sampai selepas pukul tujuh pagi dengan berbagai macam barang dagangan yang ditawarkan seperti sayur-mayur dan hasil kebun dari kampung-kampung sepanjang aliran sungai Barito dan anak-anak sungainya.

Para pedagang yang berperahu menjual hasil produksinya sendiri atau tetangganya disebut dukuh, sedangkan tangan kedua yang membeli dari para dukuh untuk dijual kembali disebut panyambangan. Keistemewaan pasar ini adalah masih sering terjadi transaksi Bapanduk antar para pedagang berperahu. ${ }^{5}$

Dalam tradisi Banjar kegiatan jual-beli mempunyai caranya sendiri. Biasanya antara penjual dan pembeli saling bertukar akad. Cara ini diajarkan ulama Banjar Syekh Muhammad Arsyad al Banjari. Ulama besar ini dikenal pula dengan nama Datu Kalampayan. Dalam kitab fiqih yang dikarang Syekh Muhammad Arsyad, mengajarkan akad jual-beli sesuai

\footnotetext{
${ }^{4}$ Sebutan perahu dalam bahasa Banjar

${ }^{5}$ Barter dalam bahasa banjar
} 
syariat Islam yang diikuti berelaan yang membuat nilai-nilai kejujuran dan kebersamaan.

Contoh pengucapaan kata akad :

a. Pihak pertama (penjual) : saya jual baju ini dengan harga Rp. 100.000 (seratus ribu rupiah)

b. Pihak kedua (pembeli) : saya beli baju tersebut dengan harga Rp. 100.000 (seratus ribu rupiah.

Selanjutnya jika, tidak mengucapkan akad tersebut, maka sesuai adat dan rukun jual beli, jual beli tersebut dianggap tidak sah, namun, terdapat sebuah pertanyaan yang timbul dari kasus tersebut, tradisi dagang orang Banjar dapat dilihat dari sikap ketika memakai akad sebagai sesuatu yang sangat prinsip sehingga mereka menganggap tidak sah suatu transaksi jika tidak dinyatakan dengan akad yang jelas. Hal semacam ini dilaksanakan tanpa melihat situasi dan kondisi dimana transaksi itu dilaksanakan, seperti apa yang terjadi di sungai pasar Terapung sebagai salah satu pusat kegiatan muamalah bagi orang Banjar. Akad jual beli di pasar Terapung dalam masyarakat Banjar telah memperhatikan asas-asas hukum yang menjadi landasan dalam rangka untuk mewujudkan "asas kemaslahatan hidup dan kebebasan dan kesukarelaan" dalam jual beli. Praktik akad jual beli/sighat di Pasar Terapung telah memenuhi Syarat akad dalam jual beli, dikarenakan perkembangan zaman yang semakin maju, apakah seorang penjual maupun pembeli di pasar terapung masih mempraktikan akad/sighat tersebut.

\section{Pokok Masalah}

2.1. Mengapa masyarakat pasar terapung Banjarmasin dalam bertransaksi jual-beli masih menggunakan pengulangan kata pada shigat akadnya.

2.2. Bagaimana pandangan masyarakat jika pengulangan kata dalam shigat akad tersebut tidak dilakukan. 


\section{Tujuan Peneletian}

3.1. Untuk mengkaji secara mendalam sebab masyarakat pasar terapung Banjarmasin dalam bertransaksi jual-beli masih menggunakan pengulangan kata pada shigat akadnya.

3.2. Untuk mengkaji secara mendalam pandangan masyarakat jika pengulangan kata dalam shigat akad tersebut tidak dilakukan.

\section{Metode Penelitian}

4.1. Jenis Penelitian

Penelitian ini menggunakan jenis penelitian social legal research yang bertujuan mengungkapkan makna yang diberikan oleh masyarakat pada perilakunya dan kenyataan sekitar. ${ }^{6}$ social legal research, penyusun rasa adalah metode yang tepat, dengan menggunakan data pengamatan budaya akad jual beli di Banjarmasin sebagai pijakan dalam pemecahan masalah yang pada dasarnya tertumpu pada penelehaan kritis dan mendalam terhadap data-data yang relevan.

\subsection{Pendekatan penelitian}

Pendekatan Normatif-Antropologis dengan pendekatan ini peneliti melacak aliran peristiwa-peristiwa yang pernah dialami manusia, termasuk proses pengembangan kebiasaan, institusi atau pemikiranpemikiran sepanjang sejarah. Di samping itu, data dapat juga diperoleh dari laporan-laporan historis dan dokumen-dokumen yang relevan, biasanya pendekatan ini mencakup dua langkah, yaitu (1) Menulusuri tahap-tahap utama dari proses perubahan yang ada (2) Menjelaskan alasan-alasan pokok mengapa perubahan-perubahan itu terjadi. Pendekatan ini dapat digunakan sendiri ataupun dapat dikombinasi dengan pendekatan-pendekatan lain, seperti pendekatan studi khusus. ${ }^{7}$

\footnotetext{
${ }^{6}$ Conny R.setyawan, Metode Penelitian Kualitatif, Jakarta: Gramedia Widiasarana, 2010, hlm. 9

${ }^{7}$ Wila Huky, Antropologi, cetakan ke-1, Surabaya: Usaha nasional, 1994, hlm. 20-21
} 


\subsection{Pengumpulan data}

\subsubsection{Observasi}

Metode ini dilakukan melalui suatu pengamatan secara langsung dan kemudian dituangkan dalam sebuah catatan yang dilaksanakan. Observasi seperti ini harus dilakukan dengan hatihati supaya tidak terkecoh oleh manipulasi pemberian informasi langsung oleh para responden. Observasi ini dilaksanakan dengan cara partisipasi, yaitu peneliti dalam usaha untuk mengumpulkan informasi yang lebih berguna, memasukkan dirinya sebagai bagian dari situasi yang sedang diteliti. ${ }^{8}$

\subsubsection{Wawancara}

Pengumpulan data dengan jalan tanya jawab sepihak yang disusun secara sistematis dan fokus kepada tujuan penelitian. Wawancara dengan Muhammad Aulia selaku Ulama di Banjarmasin, Muhammad Amin selakuTokoh Adat di Banjarmasin dan Masidah dan Jurairah, selaku Penjual di Pasar Terapung, Siring, Banjarmasin

\subsubsection{Dokumentasi.}

Metode dokumentasi adalah informasi yang berasal dari catatan penting baik dari lembaga atau organisasi maupun dari perorangan. Dokumentasi penelitian ini merupakan pengambilan gambar oleh peneliti untuk memperkuat hasil penelitian. Dokumentasi merupakan pengumpulan data oleh peneliti dengan cara mengumpulkan dokumen-dokumen dari sumber terpercaya yang mengetahui tentang nara sumber. ${ }^{9}$

\subsection{Analisis data}

Penelitian ini dalam proses penganalisisan terhadap data yang diperoleh, penyusun menggunakan metode deduktif, yaitu menganalisis norma

\footnotetext{
${ }^{8}$ Ibid, hlm.21-22

${ }^{9}$ Arikunto s, Prosedur Penelitian suatu Pendekatan Praktik, Jakarta : Rineka Cipta, 2006
} hlm. 40 . 
umum untuk menilainya menjadi khusus. Dalam penelitian ini penyusun menggunakan fakta.

\section{Hasil Penelitian dan Pembahasan}

5.1. Pasar terapung Banjarmasin

Pasar terapung muara kuin adalah sebuah pasar tradisional di Banjarmasin, Kalimantan Selatan yang berada diatas sungai Barito dimuara sungai Kuin. Aktivitas jual beli di pasar ini berlangsung diatas air dengan menggunakan perahu. Pasar ini mulai setelah shalat Subuh sampai selepas pukul tujuh pagi.

Pada awalnya kawasan Pasar Terapung lokasinya tersebar antara Kuin Utara dan Kuin Cerucuk., keberadaan Pasar Terapung memang tak lepas dengan berdirinya Kerajaan Banjar sekitar tahun 1595 oleh Sultan Suriansyah yang bergelar Pangeran Samudera. Awalnya pasar ini memang sudah ada sejak abad ke-14, sebelum Kerajaan Banjar berdiri, namun dengan berdirinya Kerajaan Banjar, pasar ini menjadi semakin hidup. Kawasan pasar apung ini merupakan bagian dari pelabuhan sungai Bandarmasih. Pelabuhan sungai ini meliputi aliran Sungai Barito, dari Sungai Kuin hingga Muara Sungai Kelayan. Berdasarkan catatan sejarahnya, Pasar Terapung merupakan pasar yang tumbuh secara alami karena posisinya yang berada di pertemuan beberapa anak sungai sehingga menjadikan kawasan ini sebagai tempat perdagangan.

Banjar memang memiliki kondisi alam yang dikenal dengan negeri seribu sungai sehingga hanya memiliki prasarana transportasi sungai. Dengan membuka lapak di sungai ini akan memudahkan para pedagang yang membawa barang dagangan berupa hasil bumi dari arah hulu untuk melakukan jual-beli. ${ }^{10}$

${ }^{10}$ Hanafiah,"akad jual beli dalam tradisi pasar terapung masyarakat banjar"Al-Tahrir, Vol. 15 (Mei 2015), hlm. 202 
Pasar Terapung semakin ramai sejak didirikannya Kerajaan Banjar dengan kenaikan Pangeran Samudera sebagai raja oleh para patih yang dipelopori oleh Patih Masih pada tahun 1526. Pasar inipun menjadi aset penting bagi ibukota kerajaan. Menurut Ayip, sapaan akrab Syarif Bistamy, keberadaan Pelabuhan Bandarmasih dan Pasar Terapung juga tak lepas dari berkembangnya Kerajaan Banjar baik secara ekonomi maupun politik. Dimana, di pusat Kerajaan Banjar di kawasan Kuin, banyak pedagang dari Jawa, Gujarat (India) dan Cina yang melakukan aktivitas perdagangan dengan masyarakat Banjar, ketika itu. Secara politik, kawasan Pasar Terapung juga tak luput menjadi medan pertempuran antara Kerajaan Banjar dengan Kerajaan Negara Daha, yang hanya terpicu dendam keluarga

Meski sempat menjadi medan pertempuran perang saudara Kerajaan Banjar, namun Pasar Terapung Muara Kuin masih tetap ada sampai sekarang. Pun ketika Kerajaan Banjar sudah runtuh, kawasan tepi Sungai Barito masih ditinggali warisan Masjid Sultan Suriansyah. Karena keunikannya, Pasar Terapung pun dijadikan aset negara oleh pemerintah Indonesia sejak tahun 1980 dan masih tetap eksotis sampai sekarang.

Pangeran Suriansyah adalah penguasa pertama yang memeluk agama Islam. Makamnya berada di Kelurahan Kuin Selatan, sebuah pemakaman yang merupakan Kompleks Pemakaman Raja-raja Banjar. Raja Banjar ke-2 Sultan Rachmatullah, Raja Banjar ke-3 Sultan Hidayatullah dan Khatib Dayan seorang ulama keturunan Arab yang diutus Sultan Trenggano untuk mengislamkan Pangeran Suriansyah, dimakamkan juga di sini. Makam ini ramai dikunjungi oleh para wisatawan mancanegara maupun wisatawan nusantara sebagai salah satu objek wisata ziarah.

Perkembangan Pasar Terapung terjadi bersamaan dengan adanya komunitas yang secara tetap mendiami daerah sekitarnya. Apabila dilihat ke masa lalu, Kuin adalah sebuah perkampungan yang sejak awal telah menjadi pusat perhatian para pedagang yang mendiami kawasan ini. 
Pedagang Melayu memang telah ada sejak sebelum terbentuknya Kerajaan Banjar. Mereka kemudian membuat permukiman di sekitar daerah muara Sungai Kuin dan hidup berdampingan dengan masyarakat beretnis Dayak yang hidup di sekitar daerah tersebut. Masing-masing kelompok dipimpin oleh seorang kepala suku (pimpinan kelompok masyarakat Melayu) yang disebut Patih, di antaranya Patih Kuin, Patih Balit, Patih Muhur dan Patih Balitung. Dengan demikian di areal muara Sungai Kuin dan sekitarnya terdapat lima kelompok suku bangsa yang hidup berdampingan secara damai. Keberadaan masyarakat dan kontak antar kelompok yang mendiami lokasi yang menjadi cikal bakal Kota Kerajaan Banjar ini melahirkan sebuah kompleks pasar di muara Sungai Kuin yang sekarang dikenal dengan Pasar Terapung.

Aktivitas pasar yang berlangsung di atas puluhan perahu ini terbentuk secara alamiah. Kondisi alam Banjar yang dikenal sebagai negeri seribu sungai ini duhulunya memang hanya memiliki prasarana transportasi sungai. Barang dagangan berupa hasil bumi dan kebun yang dibawa penduduk dari arah hulu sungai, sangat mudah dibawa dengan menggunakan perahu. ${ }^{11}$

Sebelum tahun 1950-an, ketika transportasi darat masih belum berkembang seperti dewasa ini, infrastruktur (jalanan, jembatan) maupun sarana lainnya (berjenis kendaraan bermotor), budaya sungai masih mendominasi cara hidup masyarakat. Sungai dan perahu memberikan bentuk perdagangan antar penduduk khususnya yang bermukim di tepi dan di lingkungan sungai.

Barang-barang yang diperjualbelikan ialah alat-alat dan bahanbahan pokok keperluan sehari-hari, perahu-perahu dari ukuran kecil yang dikayuh oleh penjual dan pembeli hingga perahu-perahu pengangkut yang didayung, menggerakkan kegiatan niaga itu antar desa, dari desa ke kota dan sebalinya dari pekan ke pekan pasar antar waktu tertentu lazim sehari dalam sepekan.

\footnotetext{
${ }^{11}$ http://ace-informasibudaya.blogspot.co.id/2010/05/pasar-terapung-banjarmasin.html
} 
Kota-kota kecil dan desa-desa di Tepian Sungai Barito, Sungai Bahan, Sungai Nagara, dan Sungai Martapura, tiap hari pekan selain los pasar di darat/bantaran, kegiatan jual beli juga diperluas di pasar terapung di sungai di areal los pasar itu.

Di luar hari pekan, pedagang-pedagang sungai ini memasarkan barang dagangan tertentu, biasanya alat-alat memasak/kerja dan bahan yang tahan lama dan minuman. Perahu-perahu sedemikian ini, disebut menurut barang yang dibawanya, seperti : perahu dapur, perahu singkong, perahu jagung, perahu ikan, perahu semangka, dan sebagainya. $^{12}$

5.2. Sejarah Adanya Akad Jual Beli

Adab orang Banjar ketika melakukan jual beli mengucapkan kata tukar dan jual. Ulama Banjar, syekh Muhammad Arsyad al-Banjari (datu kelampayan) dalam kitab Sabilal Muhtadin mengajarkan akad jual beli yang mengikuti syariat Islam. Pedagang pasar tradisional atau pasar terapung masih memakai sistem jual beli seperti ini. Transaksi setelah jual beli memakai ijab kabul akad jual beli. Pedagang mengucapkan jual dan yang membeli mengucapkan tukar. Akad jadi kesepakatan dalam transaksi yang diikuti berelaan yang membuat nilai-nilai kejujuran dan kebersamaan. ${ }^{13}$

Tradisi Banjar pun dalam kegiatan jual-beli ada caranya sendiri. Biasanya antara penjual dan pembeli saling bertukar akad (baca: ucapan). Tukar dan beli. Cara ini diajarkan ulama Banjar yang mendunia, Syekh Muhammad Arsyad al Banjari. Ulama besar ini dikenal pula dengan nama Datu Kalampayan. Dalam kitab fiqih yang dikarang Syekh Muhammad Arsyad, mengajarkan akad jual-beli sesuai syariat Islam. Pedagang, baik di warung-warung, pasar tradisional, dan pasar terapung, masih bertahan dengan sistem jual-beli ini. Dengan dialog dan interaksi yang luwes, transaksi pada pasar tradisional dilakukan dengan ijab qabul

\footnotetext{
${ }^{12}$ Badan penelitian dan pengembangan daerah propinsi kalimantan selatan: Urang Banjar dan Kebudayaanya, cetakan ke-1, Banjarmasin,PT. grafika wangi kalimantan, 2005, hlm. 134-135

${ }^{13} \mathrm{http}: / /$ pulaubanuabanjar.com/index.php/tulisan/baca/157/Adab-Batatukar-Urang-Banjar
} 
sebagai akad jual-beli. Pedagang biasanya mengucapkan kata "jual” atau dijual/menjual, sedangkan pembeli membalas ucapan/akad itu dengan mengucapkan "beli" atau dibeli/membeli. Akad ini menjadi syarat sah jual-beli atau berdagagang, atau badagang. Dan, dalam Islam sendiri adab jual-beli yang penting diperhatikan umat Islam.

Tradisi masyarakat Banjar menjadi fenomena yang unik. Secara simbolik, tradisi dagang orang Banjar dapat dilihat dari sikap mereka ketika memaknai akad sebagai sesuatu yang sangat prinsip, sehingga mereka menganggap tidak sah suatu transaksi jika tidak dinyatakan dengan akad yang jelas. Pernyataan yang jelas ini harus diaplikasikan dengan suatu pernyataan ijab-qabul :

Pembeli $\quad$ "cil, berapaan harga mangganya?" (harga
manganya berapa bu?)
"ulun nukar 2 biji cil" (saya beli 2 bu)

Hal semacam ini dilaksanakan tanpa melihat situasi dan kondisi di mana transaksi itu dilaksanakan, seperti apa yang terjadi disungai Pasar Terapung sebagai salah satu pusat kegiatan mu'amalah bagi orang Banjar 
5.3. Pandangan Para Ulama, Tokoh Adat dan Penjual Tentang Budaya Akad 5.3.1. Ulama

Hasil wawancara dengan tokoh ulama di Banjarmasin, Muhammad Aulia berpendapat bahwa guna berakad dalam jual beli ada dua cara, yang pertama akad itu menjatuhkan dari pada hukum halal haramnya suatu makanan yang kedua itu memang dari hukum syar'i artinya hukum yang dinyatakan oleh Imam Syafii dari pada jumhur ulama, Madzhab Imam Syafii menyatakan sah jual belinya sesuatu yang mana sebelumnya akad itu dilaksanakan maka apabila tidak dituturkan dengan perkataan, ada dua kemungkinan yang pertama halal haramnya makanan yang kedua bisa menjadikan subhat.

Akad bisa juga dilakukan dengan niatan dalam hati, artinya barang yang diperjualbelikan nampak bisa juga cukup mengucapkan kata terimakasih maka dengan itu telah sah suatu jual beli. Haram suatu akad jual beli apabila sesuatu yang diperjualbelikan bersifat najis. Akad itu menjamin suatu keabsahan halal haramnya suatu makanan atau barang.

Dasar hukum akad dibanjarmasin ada dua :

5.3.1.1. Akad yang menurut hukum syar'i / hukum yang ada dalam fiqh

5.3.1.2. Menurut madzhab syafii Hukum adat adalah hukum yang menuju kepada hukum syar'i, artinya membiasakan suatu bahasa untuk menjatuhkan hukum syar'i.

Akibat hukum apabila tidak melaksanakan akad adalah menjauhkan daripada pekerjaan yang baik menuju kepada pekerjaan yang maksiat. Sekecil apapun makanan yang masuk kedalam perut maka disanalah munculnya gejala maksiat. 
Hukum adat itu mengkiaskan suatu hukum yang dibawa kepada kebiasaan yg diambil dari hukum syar'i, hukum adat jangan sampai bertentangan dengan syara', hukum adat yg menjadi kebiasaan itu tidak masalah apabila dalam pelaksanaannya dengan niatan tidak menuhankan sesuatu. Hal itu hasanah atau dapat dibenarkan, hukum adat dapat diterima oleh akal apabila tidak bertentangan dengan aqidah, sebaliknya bisa mengakibatkan musyrik apabila bertentangan dengan normanorma hukum Islam.

Masyarakat Banjarmasin kebanyakan bertaqlid atau mengikuti orang banyak dari mulut ke mulut dalam melakukan budaya akad jual beli yang diambil dari kitab Sabilal Muhtadin dari datu kelampaian Syekh Arsyad al-Banjari, perilaku mengikuti budaya akad jual beli itu menjadi kebiasaan dan turun temurun hidup dalam perilaku sosial masyarakat Banjarmasin.

Makna pengulangan kata akad jual beli adalah menjatuhkan hukum suatu barang yang mana sebelumnya subhat menjadi halal, sesuatu barang yang belum ada akad jual beli barang itu dikatakan haram. Mengabsahkan suatu barang dalam akad jual beli menjadi suatu hal yang penting.

Dalam wawancara dengan tokoh ulama di Banjarmasin Kamarudin berpendapat bahwa guna akad budaya jual beli dibanjarmasin adalah agar tidak ada unsur tipu menipu contoh saat transaksi online, barang yang diperjual belikan disitus online terlihat bagus dan sebagian situs online tidak memberi tahu kekurangan dari barang tersbut. 
Selanjutnya guna akad jual beli adalah agar penjual dan pembeli puas terhadap barang yang diperjualbelikan karena kedua belah pihak langsung atau Nampak melihat barang tersebut saat transaksi. ${ }^{14}$

\subsubsection{Tokoh adat}

Pada kesempatan wawancara dengan tokoh adat di Banjarmasin, M.Amin berpendapat bahwa tidak hanya dalam jual beli buah-buahan atau benda saja yang harus menggunakan akad. Saat kita makan di warung makan pun juga harus memakai akad, kebiasaan orang banjar ketika makan di warung makan adalah akad dilakukan setelah selesai makan, padahal seharusnya akad dilakukan ketika memesan makanan. Hal ini menandakan bahwa esensi dari suatu akad itu sangat vital fungsinya, mengingat akad menjadi syarat sahnya transaksi jual beli.

Nilai kelebihan budaya akad tersebut bukan hanya untuk halalnya suatu jual beli saja, melainkan agar hati penjual dan pembeli senang dan ikhlas. Fenomena ini didasari oleh ittikad baik masyarakat Banjarmasin guna kejujuran, keterus terangan dan bentuk penghormatan terhadap orang lain. Ittikd baik ini menjadi sebuah keunikan dan buah budaya masyarakat lokal yang menjunjung tinggi asas keterbukaan dan asas keadilan, semua ini bertujuan agar transaksi jual beli tersebut sama-sama memberikan manfaat bagi para pihak, serta menghindarkan keduanya dari bentuk-bentuk kerugian yang mungkin bisa di alami oleh para pihak.

Melakukan akad juga harus memperlihatkan barang yang diperjualbelikan dan atau memastikan barang itu ada, tidak sah suatu akad apabila barang itu tidak nampak secara langsung.

14 Wawancara dengan Muhammad Aulia, Ulama di Gambut, Banjarmasin, Kalimantan Selatan, tanggal 14 Februari 2018. 
Ada tiga keutamaan dalam akad jual beli di Banjarmasin yakni ikhlas, jujur dan benar. Pertama yakni ikhlas, artinya dalam jual beli itu didasari oleh kerelaan dari para pihak yang bertransaksi. Pihak pembeli memang benar-benar membutuhkan barang atau benda tertentu, dan pihak penjual benar-baner berniat menjualnya tanpa paksaan. Kedua yakni jujur, disini jujur dimaksudkan para pihak transparan dalam penjelasan kondisi barang atau benda dan juga pada kebutuhannya. Para pihak menghindari perilakuperilaku yang mengindikasikan kecurangan serta kebohongan, demikian ini agar semua pihak dapat bertransaksi dengan baik dan nyaman . Ketiga yakni benar, maksud dari benar ini sesuai dengan syarat dan rukun jual beli yang diatur dalam hukum Islam. Transaksi yang tidak bertentangan serta tidak membawa kepada madharat, baik bagi para pihak ataupun masyarakat umum. ${ }^{15}$

\subsubsection{Penjual Pasar Terapung Banjarmasin}

Hasil wawancara dengan pihak penjual pasar terapung Banjarmasin, Masidah dan Jurairah (penjual buah dan sayur pasar terapung) berpendapat bahwa apabila suatu transaksi jual beli dilakukan diatas perahu dan diterjang ombak yang mengakibatkan akad tukar jual tidak tersampaikan, maka transaksi jual beli itu tidak sah, oleh sebab itu sampai sekarang akad jual beli tersebut masih digunankan, dikarenakan akad tersebut wajib dilakukan dan sudah menjadi kebudayaan yang sudah lama ada, tujuan dari adanya budaya akad jual beli di Banjarmasin adalah agar seseorang yang melakukan akad jual beli tersebut memiliki keikhlasan dalam melakukan transaksi jual beli baik penjual maupun pembeli.

${ }^{15}$ Wawancara dengan Muhammad Amin, Tokoh Adat, Banjar, Banjarmasin, Kalimantan Selatan tanggal 12 Februari 2018. 
Penjual dan pembeli wajib saling menghormati dalam transaksi jual beli dikarenakan apabila salah satu pihak tidak menghormati otomatis jual beli itu bisa dikatakan tidak ikhlas, apabila si penjual menghormati pasti si pembeli juga menghormati dan sebaliknya. Bentuk akad tukar jual ini menjunjung tinggi nilai kemanfaatan, artinya para pihak baik penjual dan pembeli sama-sama dapat berterus terang tentang kondisi barang atau benda yang bersangkutan dengan sempurna.

Selanjutnya apabila si pembeli adalah non muslim atau orang asing dikarenakan mereka tidak mengerti dengan adanya akad dalam transaksi jual beli di Banjarmasin maka akad itu dilakukan oleh si penjual saja, dan menerima tidaknya non muslim tersebut asalkan telah gugur kewajiban dari si penjual maka transaksi jual beli tersebut sudah dikatakan sah. Misalnya kita cukup mengatakan kata terimakasih kepada non muslim atau orang asing jual beli itu sudah sah.

Dalam transaksi jual beli yang dilakukan diatas perahu ada kemungkinan adanya cacat dalam jual beli, sebagai contoh dalam jual beli buah-buahan, ada jatuh salah satu buah rambutan maka si penjual akan mengucapkan akad "jual seadanya" yang artinya saya jual buah ini dengan apa adanya. Setelah itu tergantung si pembeli, apabila si pembeli ikhlas maka si pembeli mengucapkan "tukar jua seadanya" yang artinya saya beli buah ini dengan kondisi apa adanya dengan akad seperti maka timbul hati yang ikhlas dalam transaksi jual beli. Pihak penjual menjelaskan secara rinci kondisi buah yang dijualnya, dan pihak pembeli mengetahui kekurangan terhadap buah yang hendak dibelinya, dan ia tetap menerimanya dengan ikhlas tanpa keberatan.

Saat terjadi jual beli banyak pembeli yang datang membeli dan praktik akad sangat tidak memungkinkan, maka akad akan tetap dilakukan dengan cara si penjual tetap mengucapkan akad 
walaupun si pembeli tidak mendengar akad tersebut, dan ini tetap sah dikarenakan situasi yang tidak memungkinkan. Hal seperti ini dapat dimaklumi karena keadaan yang tidak mendukung dan tidak kondusif guna penggunaan akad tukar jual yang sempurna oleh penjual dan pembeli sekaligus.

Keunikan berakad jual beli di Banjarmasin adalah "bagus lawan sopan" kita berakad berarti kita menghormati sesama biar "hati nyaman" dan "meambil berakat" kita jual seadanya kita tukar seadanya. Artinya akad ini bertujuan untuk menjamin kemanfaatan yang diperoleh penjual dan pembeli, dengan adanya bentuk penghormatan lewat akad yang baik tersebut, maka penjual pembeli berharap mendapat keberkahan dari bentuk transaksi yang menjunjung tinggi nilai kejujuran dan kebaikan bersama $^{16}$

Berdasarkan hasil Observasi yang penyusun lihat di lapangan, akad jual beli yang terjadi di Pasar Terapung Banjarmasin masih dilakukan oleh penjual maupun pembeli dipasar terapung Banjarmasin, karena dibanjarmasin akad jual beli itu menjadi suatu hukum adat yang mana hukum adat tersebut muncul karena adanya hukum syar'i, apabila suatu hukum adat itu dilaksanakan maka akan menjadi suatu perantara hukum menuju hukum syar'i.

5.4. Makna pengulangan kata akad ditinjau dari aspek normatif dan antropologis

5.4.1. Nilai transparansi dan keridhoan kedua belah pihak

Nilai kelebihan budaya akad tersebut bukan hanya untuk halalnya suatu jual beli saja, melainkan agar hati penjual dan pembeli senang dan ikhlas. Fenomena ini didasari oleh ittikad baik masyarakat Banjarmasin guna kejujuran, keterus terangan

16 Wawancara dengan Masidah dan Jurairah, Penjual di Pasar Terapung, Siring, Banjarmasin, Kalimantan Selatan, tanggal 11 Januari 2018. 
dan bentuk penghormatan terhadap orang lain. Ittikad baik ini menjadi sebuah keunikan dan buah budaya masyarakat lokal yang menjunjung tinggi asas keterbukaan dan asas keadilan, semua ini bertujuan agar transaksi jual beli tersebut sama-sama memberikan manfaat bagi para pihak, serta menghindarkan keduanya dari bentuk-bentuk kerugian yang mungkin bisa di alami oleh para pihak. Allah berfiman : ${ }^{17}$

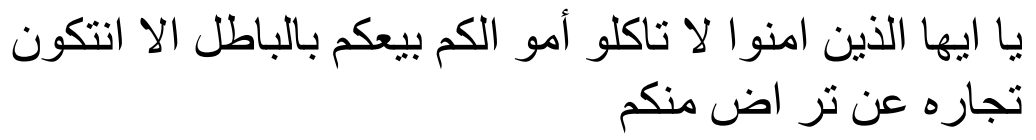

Dalil diatas bermakna bahwa dalam suatu transaksi jual beli kita diharuskan untuk memiliki kerelaan dan dilarang memakan harta sesama dengan cara yang bathil. Dengan cara transaparan atau kejujuran maka kerelaan lebih mudah untuk didapatkan dengan kerelaan pula suatu jual beli akan bernilai positif dan membawa kemaslahatan dan menghindari dari kemudhratan.

\subsubsection{Nilai kebaikan}

Adapun nilai lainnya adalah menjauhkan daripada pekerjaan yang maksiat, yang dimaksud disini adalah praktek jual beli yang tidak didasari oleh kejujuran, keridhoaan kedua belah pihak menuju kepada pekerjaan yang baik. Artinya terdapat ittikad baik bagi kedua belah pihak untuk bertransaksi secara transparan dan bermuara pada keridhoan Allah. Dengan bertransaksi berdasarkan nilai-nilai kebaikan, para pihak tidak serta merta hanya mengejar keuntungan dan kebutuhan melainkan juga keberkahan yang dilandasasi kerelaan dan ittikad baik.

Ada tiga keutamaan dalam akad jual beli dibanjarmasin yakni ikhlas, jujur dan benar. Pertama yakni ikhlas, artinya dalam jual beli itu didasari oleh kerelaan dari para pihak yang

${ }^{17}$ an-Nisa(4): 29 
bertransaksi. Pihak pembeli memang benar-benar membutuhkan barang atau benda tertentu, dan pihak penjual benar-baner berniat menjualnya tanpa paksaan. Kedua yakni jujur, disini jujur dimaksudkan para pihak transparan dalam penjelasan kondisi barang atau benda dan juga pada kebutuhannya. Para pihak menghindari perilaku-perilaku yang mengindikasikan kecurangan serta kebohongan, demikian ini agar semua pihak dapat bertransaksi dengan baik dan nyaman. Ketiga yakni benar, maksud dari benar ini sesuai dengan syarat dan rukun jual beli yang diatur dalam hukum Islam. Transaksi yang tidak bertentangan serta tidak membawa kepada madharat, baik bagi para pihak ataupun masyarakat umum.

Berakad dalam jual beli ada dua cara, yang pertama akad itu menjatuhkan dari pada hukum halal haramnya suatu makanan yang kedua itu memang dari hukum syar'i artinya hukum yang dinyatakan oleh imam Syafii dari pada jumhur ulama, madzhab imam syafii menyatakan sah jual belinya sesuatu yang mana sebelumnya akad itu dilaksanakan maka apabila tidak dituturkan dengan perkataan, ada dua kemungkinan yang pertama halal haramnya makanan yang kedua bisa menjadikan subhat.

Hukum adat itu mengkiaskan suatu hukum yang dibawa kepada kebiasaan yang diambil dari hukum syar'i, hukum adat jangan sampai bertentangan dengan syara', hukum adat yg menjadi kebiasaan itu tidak masalah apabila dalam pelaksanaannya dengan niatan tidak menuhankan sesuatu. Hal itu hasanah atau dapat dibenarkan, hukum adat dapat diterima oleh akal apabila tidak bertentangan dengan aqidah, sebaliknya bisa mengakibatkan musyrik apabila bertentangan dengan normanorma hukum Islam. 
5.5. Faktor-faktor yang mengkokohkan penggunaan ulang kata dalam IjabQabul pada Pasar Terapung Banjarmasin.

Praktik jual beli yang dilakukan oleh masyarakat Banjar memiliki keunikan tersendiri, yaitu dengan melakukan akad jual beli di tengahtengah sungai yang disebut 'Pasar Terapung'. dimana jika para pihak melaksanakan jual beli di Pasar Terapung Banjarmasin, maka keduanya mereka "wajib" mengucapkan kata akad dan selanjutnya jika tidak mengucapkan akad tersebut, maka sesuai adat dan rukun jual beli, jual beli dihukum tidak sah. Kemunculan Pasar Terapung tentunya terkait erat dengan kondisi geografis wilayah Banjar yang memang banyak sungai sehingga wilayah ini dikenal dengan sebutan kota seribu sungai.

Dalam transaksi di Pasar Terapung tersebut, penjual dan pembeli tetap melakukan akad jual beli sesuai dengan ketentuan hukum Islam, padahal sebenarnya situasi dan kondisi ketika itu tidak memungkinkan untuk transaksi seperti jual beli biasa karena sampan yang mereka gunakan sebagai alat transportasi tersebut digoncang oleh ombak sungai. Di samping itu, keleluasaan untuk memilih barang juga kurang memungkinkan, belum lagi barang yang diperjualbeli kan juga tidak bisa dilihat secara lebih jelas.

Berdasarkan hasil riset yang telah dilaksanakan dari beberapa pendapat para tokoh adat dan ulama di Banjarmasin maka diketahui terdapat beberapa faktor yang mempengaruhi pelaksanaan shigat akad dalam praktik jual beli pasar terapung Banjarmasin, seperti adanya pengaruh tradisi keagaman.

Masyarakat Banjarmasin kebanyakan bertaqlid atau mengikuti orang banyak dari mulut ke mulut dalam melakukan budaya akad jual beli yang diambil dari kitab sabilal muhtadin dari datu kelampaian Syekh Muhammad Arsyad al-Banjari, perilaku mengikuti budaya akad jual beli itu menjadi kebiasaan dan turun temurun hidup dalam perilaku sosial masyarakat Banjarmasin. Akad tersebut timbul pertama kali di pasar terapung Lok Baintan dari nenek datu yang sudah lebih dulu 
melestarikan budaya akad tersebut. Kebiasaan yang turut didukung oleh tokoh masyarakat menjadikan masyarakat meyakini budaya akad jual beli tersebut suatu keniscayaan yang pantas untuk diteruskan dan dilestarikan. Terlebih budaya tersebut mempunyai nilai-nilai fundamental yang mulia, terutama demi keridhoan para pihak yang bertujuan mencapai kemaslahatan.

Budi pekerti orang banjar ketika melakukan jual beli mengucapkan kata tukar dan jual. Ulama banjar, Syekh Muhammad Arsyad al-Banjari (datu kelampayan) dalam kitab sabilal muhtadin mengajarkan akad jual beli yang mengikuti syariat islam. Pedagang pasar tradisional atau pasar terapung masih memakai sistem jual beli seperti ini, transaksi setelah jual beli memakai ijab kabul akad jual beli. Pedagang mengucapkan jual dan yang membeli mengucapkan tukar. Akad jadi kesepakatan dalam transaksi yang diikuti berelaan yang membuat nilai-nilai kejujuran dan kebersamaan. ${ }^{18}$

Perilaku budaya masyarakat Banjarmasin yang melestarikan jual beli yang demikian didukung oleh akses-akses pengajian atau perkumpulan masyarakat yang disitu terdapat tokoh agama atau ulama yang menjadi panutan di Banjarmasin ajaran agama islam sangat kuat dan kental, masuk ke aspek-aspek kehidupan sosial masyarakat Banjarmasin. Ajaran islam dianggap sebagai sumber inspirator berprilaku dalam kehidupan sehari-hari. Hal tersebut didukung dengan tingkat pemahaman dan penguasaan hukum Islam yang sangat baik oleh ulama di Banjarmasin bahkan diantaranya dianggap sebagai wali Allah yang mempunyai karomat. Maka sudah seharusnya masyarakat Banjarmasin mengikuti kebiasaan ataupun prilaku yang diajarkan oleh ulama-ulama tersebut.

Jual beli dengan pengulangan kata bertujuan untuk mencari kerelaan yang sempurna dari para pihak. Maka selayaknya masyarakat Banjaramasin sepaham dengan perilaku budaya demikian, yang mana

\footnotetext{
${ }^{18}$ http://pulaubanuabanjar.com/index.php/tulisan/baca/157/Adab-Batatukar-Urang-Banjar
} 
memberatkan pada keridhoan yang mempunyai tujuan mulia demi tercapainya jual beli yang bermanfaat dan berkah.

Dikaitkan dengan pasar terapung bahwa jika diterapkan dengan praktik transaksi jual beli dipasar terapung tersebut, penjual dan pembeli tetap melakukan akad jual beli sesuai dengan ketentuan hukum Islam, padahal sebenarnya situasi dan kondisi ketika itu tidak memungkinkan untuk transaksi seperti jual beli biasa karena sampan yang mereka gunakan sebagai alat transportasi tersebut digoncang oleh ombak sungai. Di samping itu, keleluasaan untuk memilih barang kurang memungkinkan, belum lagi barang yang diperjualbelikan juga tidak bisa dilihat secara lebih jelas.

Ulama mazhab Syafi'i dalam qaul qadim (pendapat lama) tidak membenarkan akad tersebut karena kedua belah pihak harus menyatakan secara jelas mengenai ijab dan qabul itu, namun mayoritas ulama, termasuk mazhab Syafi'i generasi belakangan, seperti Imam al-Nawawi, membolehkan jual beli seperti tersebut di atas karena telah menjadi adat kebiasaan dalam masyarakat sebagian besar umat Islam.

Menurut Mustafa al-Zarqa', suatu akad di pandang sempurna apabila telah memenuhi syarat-syarat yang di sebut kan di atas, namun ada akad-akad yang baru dipandang sempurna apabila telah dilakukan timbangan terima dan tidak memadai hanya dengan ijab dan qabul saja, yang disebut dengan al'uqud al-ayniyyah yaitu adalah akad yang berhubungan dengan suatu benda secara fisik. Contohnya pada transaksitransaksi seperti transaksi jual beli, hibah, sedekah, sewa menyewa, titipan (wadiah), dan gadai (rahn). Menurut ulama' fiqh, lima macam akad (transaksi) tersebut harus diserahkan kepada yang berhak dan dikuasai sepenuhnya, dan tidak boleh terlepas dari tanggung jawab. Syarat shighat menurut madzhab Shāfi'ī adalah berhadap-hadapan. Pembeli dan penjual harus menunjukkan shighat akadnya kepada orang yang sedang bertransaksi dengannya, yakni harus sesuai dengan orang yang dituju. 
Dengan demikian, tidak sah berkata, "Saya menjual kepadamu!". Tidak boleh berkata, "Saya menjual kepada Ahmad", padahal nama pembeli bukan Ahmad. Pendapat lain adalah penyampaian akad dengan perbuatan atau disebut juga dengan aqad bi al-mu'athah, yaitu penyampaian akad dengan perbuatan atau "Mengambil dan memberikan dengan tanpa perkataan (ijab qabul), sebagaimana seseorang membeli sesuatu yang telah diketahui harganya, kemudian ia mengambilnya dari penjual dan memberikan uangnya sebagai pembayaran". Dapat disimpulkan bahwa ketika seseorang melakukan kontrak perjanjian dalam bidang mu'amalah, maka sesungguhnya dia tidak harus memaksakan sesuatu yang sulit. Artinya, dia dapat melakukan dengan tetap memperhatikan asas-asas hukum yang menjadi tumpuan dan landasan dalam rangka untuk melindungi dan menjaga kepentingannya, sebagaimana apa yang disebut dengan "asas kemaslahatan hidup dan asas kebebasan dan kesukarelaan". Dengan demikian, hukum akad jual beli Pasar Terapung dalam tradisi masyarakat Banjar dapat dikatakan sah jual belinya karena telah sesuai asas kemaslahatan dan kesukarelaan melalui simbol-simbol tradisi dalam Pasar Terapung.

\section{Kesimpulan}

6.1. Akad jual beli di pasar terapung Banjarmasin merupakan adat kebiasaan yang telah ada sejak dulu dan sudah menjadi suatu kebudayaan, shigat akad tersebut adalah penggabungan antara hukum Islam dengan hukum adat yang mana hukum adat itu mengkiaskan suatu hukum yg dibawa kepada kebiasaan yg diambil dari hukum syar'I atau hukum Islam. Akad jual beli di Pasar Terapung dalam masyarakat Banjar telah memperhatikan asas-asas hukum yang menjadi landasan dalam rangka untuk mewujudkan asas kemaslahatan hidup dan asas kebebasan, kesukarelaan dalam jual beli. Praktik akad jual beli di Pasar Terapung telah memenuhi syarat akad dalam jual beli, yang inti nya adalah mengarah pada kerelaan dan kesepahaman antara penjual dan pembeli. 
Shigat akad dapat bertahan hingga sekarang dikarenakan masyarakat Banjarmasin memiliki kepercayaan bahwa akad tersebut sesuai dengan ketentuan syari'at Islam.

6.2. Ulama banjar, Syekh Muhammad Arsyad al-Banjari (datu kelampayan) dalam kitab sabilal muhtadin mengajarkan akad jual beli yang mengikuti syariat islam. Pedagang pasar tradisional atau pasar terapung masih memakai sistem jual beli seperti ini, transaksi setelah jual beli memakai ijab kabul akad jual beli. Pedagang mengucapkan jual dan yang membeli mengucapkan tukar. Akad jadi kesepakatan dalam transaksi yang diikuti berelaan yang membuat nilai-nilai kejujuran dan kebersamaan. Dalam transaksi di Pasar Terapung tersebut, penjual dan pembeli tetap melakukan akad jual beli (ijab qabul) sesuai dengan ketentuan hukum Islam, Keadaan kondisi pasar terapung demikian padahal sebenarnya situasi dan kondisi ketika itu tidak memungkinkan untuk transaksi jual beli biasa karena sampan yang mereka gunakan sebagai alat transportasi tersebut digoncang oleh ombak sungai. Menurut ulama syafi'iyah, "Tidak sah akad jual beli kecuali dengan shighat (ijab qabul) yang diucapkan". 


\section{DAFTAR PUSTAKA}

\section{Literatur Ilmiah}

Anwar, Syamsul, Hukum Perjanjian Syariah, cetakan ke-2, Jakarta: Rajawali Pers, 2010.

Arikunto s, Prosedur Penelitian suatu Pendekatan Praktik, Jakarta : Rineka Cipta, 2006.

Badan penelitian dan pengembangan daerah propinsi kalimantan selatan: Urang Banjar dan Kebudayaanya, cetakan ke-1, Banjarmasin,PT. grafika wangi kalimantan, 2005.

Huky, Wila, Antropologi, cetakan ke-1, Surabaya: Usaha nasional, 1994.

Hanafiah,"akad jual beli dalam tradisi pasar terapung masyarakat banjar"AlTahrir, Vol. 15 (Mei 2015).

R.setyawan, Conny, Metode Penelitian Kualitatif, Jakarta: Gramedia Widiasarana, 2010.

Suhendi, Hendi, Fiqh Muamalah, cetakan ke-8, Jakarta: Rajawali, 2013.

\section{Hasil Wawancara}

Wawancara dengan Muhammad Aulia, Gambut, Banjarmasin, Kalimantan Selatan, tanggal 14 Februari 2018.

Wawancara dengan Muhammad Amin, Tokoh Adat, Gambut, Banjarmasin, Kalimantan Selatan tanggal 12 Februari 2018.

Wawancara dengan Masidah dan Jurairah, Penjual di Pasar Terapung, Siring, Banjarmasin, Kalimantan Selatan, tanggal 11 Januari 2018.

\section{Media Online}

http://ace-informasibudaya.blogspot.co.id/2010/05/pasar-terapungbanjarmasin. html

http://pulaubanuabanjar.com/index.php/tulisan/baca/157/Adab-BatatukarUrang-Banjar

http://pulaubanuabanjar.com/index.php/tulisan/baca/157/Adab-BatatukarUrang-Banjar

\section{Lain-lain}

Al-Qur'an 